\title{
Investigation of zeolite supported platinum electrocatalyst for electrochemical oxidation of small organic species
}

\author{
Jun $\mathrm{Yao}^{1 *}$ and Yufeng $\mathrm{Yao}^{2}$ \\ ${ }^{1}$ School of Engineering, University of Lincoln, Brayford Pool, Lincoln LN6 7TS, UK \\ ${ }^{2}$ Department of Engineering Design and Mathematics, University of the West of England, Bristol \\ BS16 1QY, UK

\section{Highlights} \\ - Pt ion exchange with $Y$ type zeolite and calcination and reduction. \\ - $\mathrm{H}^{+}$spillover at electrode and solution interface and through zeolite framework. \\ - Pt particle size measurement by EXAFS. \\ - Pt electrocatalytic performance by CV measurement. \\ - Electro-oxidation of small organic species on Pt surface.
}

Abstract: Zeolite supported Pt electrocatalysts, made by ion exchange method using $\mathrm{Pt} / \mathrm{Y}$ type zeolite, have been investigated to determine Pt electrochemical activity of $\mathrm{HCOOH}$ and $\mathrm{CH}_{3} \mathrm{OH}$ oxidation using the cyclic voltammetry (CV) and the extended X-ray adsorption fine structure (EXAFS) techniques. The study reveals that the introduction of excess $\mathrm{H}^{+}$ions during electrocatalyst pre-treatment could enhance electrochemical reaction on Pt surface due to higher Pt dispersion, regardless of zeolite being a direct current electronic conducting insulator. Two possible conduction pathways might contribute to the electrocatalytic reaction on Pt surface with Pt particle size and loading: (1) hydrogen atoms $/ \mathrm{H}^{+}$ions spillover through zeolite framework and at the electrode and solution interface; (2) surface mobility of adsorbed species on electrode surface. The water may act as a carrier in assisting the migration of the $\mathrm{H}^{+}$ions throughout zeolite channels to facilitate the charger and electron transfer in such an electrical system.

Keywords: Pt on $\mathrm{Y}$ zeolite, $\mathrm{H}^{+}$spillover species surface mobility, $\mathrm{HCOOH}$ and $\mathrm{CH}_{3} \mathrm{OH}$ oxidation, $\mathrm{CV}$, EXAFS.

\section{Introduction}

Carbon supported platinum (Pt/C) as a common type of electrocatalyst has been widely used in direct methanol fuel cell (DMFC) applications with Pt loading on carbon normally in a range of $20 \%$ $40 \%$, which is prohibitively expensive. Furthermore, the $\mathrm{Pt} / \mathrm{C}$ electrocatalysts can contain large-size

*Correspondent author. Tel: +44 (0)1522 837919

Email: jvao@lincoln.ac.uk 
Pt particles that may decrease the electrocatalytic activity. Previous study by Min et al. [1] revealed the increase of specific activities with the decrease of the surface area for carbon supported Pt electrocatalyst, in which the oxygen reduction on Pt surface was a structure-sensitive reaction associated with the adsorption strength of oxygen intermediate on the Pt surface. Hence, considerable research efforts have been made in the past decades by developing a highly dispersed nanostructured Pt electrocatalyst to improve fuel cell efficiency and economic viability for energy applications.

Zeolite can provide an environment to produce highly dispersed Pt metal particle, owing to its high selectivity and great capacity of absorbing and retaining water by the creation of zeolite proton conducting membranes for solution like ionic conduction through interconnecting channels without damaging the zeolite crystalline lattice structure [2-4]. The growth of Pt particle on zeolite is mainly controlled by $\mathrm{O}_{2}$ calcination step in gas phase and high dispersion of Pt can be achieved by further $\mathrm{H}_{2}$ reduction step [5]. A slow heating process at a high $\mathrm{O}_{2}$ flowrate would be preferable to avoid Pt nonuniform distribution on zeolite introduced by auto-reduction [6] that may produce large Pt metal particles during the removal of ammonia ligands at $300{ }^{\circ} \mathrm{C}$ [7-9]. Pt is also found favourable to remain in the zeolite supercage at $350{ }^{\circ} \mathrm{C}$ in $\mathrm{O}_{2}$ and $400{ }^{\circ} \mathrm{C}$ in $\mathrm{H}_{2}$, respectively, resulting in a particle size of $0.6-1.3 \mathrm{~nm}$, which is much smaller than that of graphene based materials with Pt particle size growing up to $1.5-19 \mathrm{~nm}[10]$.

Pt was more stable at zeolite sodalite cage, mainly due to its strong polarization nature of the Pt-d bond electron configuration [11]. A high degree of Pt dispersion was reported in the presence of $\mathrm{H}^{+}$ ions by forming $\mathrm{Pt}-\mathrm{H}$ adduct in zeolite structure. $\mathrm{H}^{+}$ions can act as a chemical anchor to diminish the sintering of Pt particles at $400{ }^{\circ} \mathrm{C}$ in $\mathrm{H}_{2}$. The polarization of Pt particles by the nearby cations, i.e. $\mathrm{H}^{+}$, might result in the electron deficiency of Pt, leading to the change of Pt catalytic activity and spectroscopic properties [12, 13]. Moreover, the charge transfer between $\mathrm{Pt}$ and nearby neighbouring zeolite support oxygen atoms can play an important role during this process $[14,15]$.

The disorder of Pt particle on zeolite framework has had a dramatic effect on the Pt electronic structure by the extended X-ray adsorption fine structure (EXAFS) [16, 17]. The Pt-Pt bond distance was shortened to less than $2.75 \AA$ than that of Pt bulk metal in the presence of strong charger transfer between Pt clusters with the increase of the Pt-Pt binding energy due to Pt electron deficiency [18], compared to $\mathrm{Pt}$ in a non-zeolite supported system, i.e. $\mathrm{Pt} / \mathrm{SiO}_{2}$. Vaarkamp et al. [19] predicted an average Pt particle size consisting of approximately 15 atoms with the first shell coordination number and Pt-Pt distance of 5.5 and $2.75 \AA$, respectively.

The electrochemical activity of Pt nanostructure on zeolite was previously investigated by Rolison et al. [4]. The Pt was found to exhibit particular chemical and physical characteristics that could enhance the electrochemical reaction, owing to high ionic strength between electrodes. Liu et al. [20] suggested that hydrogen spillover is an important process to promote Pt electrocatalysis for $\mathrm{Pt} / \mathrm{C}$ electrode. The $\mathrm{H}^{+}$ions adsorbed on the Pt active surface could spillover and diffuse into the surface of the inert support to form acidic surface oxides for an interfacial reaction of electrocatalytic process being taken place on Pt surface. The spillover of hydrogen has been discovered in both $\mathrm{Pt} / \mathrm{Al}_{2} \mathrm{O}_{3}$ and $\mathrm{Pt} / \mathrm{SiO}_{2}$ catalyst systems to promote the transport of an active species between catalyst active sites. Zhang et al. [21] also observed hydrogen spillover from Pt to zeolite Brønsted and Lewis acidic sites in gas phase. 
Pt appears to be one of the best catalysts for dissociating the $\mathrm{C}-\mathrm{H}$ bound at a relatively low potential [22], which is favourable to oxidise small organic species, such as, methanol $(\mathrm{CH} 3 \mathrm{OH})$ and formic acid $(\mathrm{HCOOH})$. However, past studies showed that the high electrocatalytic activity of Pt for methanol oxidation can be attributed by both high dispersion of redox-active Pt nanocrystal and active sites in high surface area of catalyst support, i.e. ZSM-5 zeolite [23]. Hsieh et al. [24] also discovered that Pt catalyst supported by material containing oxygen function groups, e.g. graphene oxides, is much more favourable for $\mathrm{HCOOH}$ oxidation, owing to strong interactions between metal ions and oxidised substrates, thus limiting the CO poison on Pt surface. El-Nagar and Mohammed [25] has drawn a similar conclusion about an oxygen atmosphere being important to facilitate CO oxidation at a low potential level.

Zeolite can offer high active sites interconnected by oxygen atom to enhance Pt dispersion and nucleation. However, the electrochemical oxidation and the reduction of $\mathrm{CH}_{3} \mathrm{OH}$ and $\mathrm{HCOOH}$ species on zeolite supported Pt with regard to hydrogen spillover process at the Pt/Y zeolite electrode and solution interface have not yet been fully investigated, since zeolite lacks the direct current (DC) electronic conduction, and the electro-organic reaction on $\mathrm{Pt}$ surface is generally a slow process due to the restriction of high current density generation [26].

In this study, laboratory made $1.5 \mathrm{wt} \%$ and $5 \mathrm{wt} \%$ loading Pt electrocatalysts with or without excess $\mathrm{H}^{+}$ions, introduced into zeolite structure by ion exchange method, will be investigated to determine the Pt electrochemical activity to oxidise $\mathrm{CH}_{3} \mathrm{OH}$ and $\mathrm{HCOOH}$ species by cyclic voltammetry (CV). The Pt particle size and dispersion on zeolite will be characterised by EXAFS using a Nafion ${ }^{@}$ bound electrode, fabricated by Pt/zeolite and carbon powder mixed with Nafion ${ }^{@}$ to form ultra-thin film and membrane on electrode surface [2,3]. The charger/electron transfer at electrode and solution interface will be investigated to understand Pt and zeolite conducting pathway, especially in the presence of excess $\mathrm{H}^{+}$ion on zeolite.

\section{Experimental}

\subsection{Pt/Y zeolite electrocatalysts ion exchanged using $\mathrm{Pt}\left(\mathrm{NH}_{3}\right)_{4}\left(\mathrm{NO}_{3}\right)_{2}$ or $\mathrm{Pt}\left(\mathrm{NH}_{3}\right)_{4}\left(\mathrm{NO}_{3}\right)_{2} / \mathrm{NH}_{4} \mathrm{NO}_{3}$ salts}

The $1.5 \mathrm{wt} \%$ and $5 \mathrm{wt} \% \mathrm{Pt}$ loading on $\mathrm{Y}$ zeolite electrocatalysts was made by ion exchange method $[17,18]$ using $\mathrm{Pt}\left(\mathrm{NH}_{3}\right)_{4}\left(\mathrm{NO}_{3}\right)_{2}$ salt (denoted as 15 Ptancr4 for $1.5 \mathrm{wt} \% \mathrm{Pt}$ loading and 5 Ptancr4 for 5 wt\% Pt loading on $\mathrm{Y}$ zeolite thereafter) or $\mathrm{Pt}\left(\mathrm{NH}_{3}\right)_{4}\left(\mathrm{NO}_{3}\right)_{2} / \mathrm{NH}_{4} \mathrm{NO}_{3}$ salt (denoted as 15 Ptanxcr4 for 1.5 wt\% Pt loading and 5Ptanxcr4 for $5 \mathrm{wt} \% \mathrm{Pt}$ loading on $\mathrm{Y}$ zeolite thereafter) in neutral solution, respectively.

An appropriate quantity of $\mathrm{Pt}\left(\mathrm{NH}_{3}\right)_{4}\left(\mathrm{NO}_{3}\right)_{2}$ was thoroughly dissolved in $200 \mathrm{ml}$ of triply distilled water. The ion exchange process was then taken place in water-jacketed reactor, where the sodium $\mathrm{Y}$ zeolite powder was dispersed at a concentration of $1 \mathrm{~g}$ per $100 \mathrm{ml}$. The Pt ion was slowly added by pumping $\mathrm{Pt}\left(\mathrm{NH}_{3}\right)_{4}\left(\mathrm{NO}_{3}\right)_{2}$ salt solution into the reactor. The sample was then washed with triply distilled water until no [Pt( $\left.\left(\mathrm{NH}_{3}\right)_{4}\right]^{2+}$ complex detected by Ultraviolet (UV) [27]. After washing, sample was later dried overnight in an oven. 
In case of the excess nitrate ion exchange method using $\mathrm{Pt}\left(\mathrm{NH}_{3}\right)_{4}\left(\mathrm{NO}_{3}\right)_{2} / \mathrm{NH}_{4} \mathrm{NO}_{3}$, the $\mathrm{NH}_{4} \mathrm{NO}_{3}$ was added firstly into the suspended zeolite using stoichiometric titration method to provide a $\mathrm{NH}_{4} \mathrm{NO}_{3}$ concentration of $0.063 \mathrm{~mol} \mathrm{dm}$ prior to the adding of the $\mathrm{Pt}\left(\mathrm{NH}_{3}\right)_{4}\left(\mathrm{NO}_{3}\right)_{2}$ salt.

\subsection{Calcination and Reduction}

The synthesis of Pt nanostructures on $\mathrm{Y}$ zeolite was carried out by applying the calcination and reduction procedure to remove the Pt co-ordinate ligand, i.e. a crucial chemical step associated to the formation of Pt nano-particle dispersion on zeolite substrate [8].

$\mathrm{Pt}\left(\mathrm{NH}_{3}\right)_{4}\left(\mathrm{NO}_{3}\right)_{2}$ salt $\mathrm{Y}$ zeolite samples were purged with argon at a moderate temperature in a fluidized bed reactor to dry out the water moisture. This will avoid the growth of large-size Pt particles [9]. After cooling, $\mathrm{O}_{2}$ gas was introduced into the reactor to re-heat samples up to $350{ }^{\circ} \mathrm{C}$. Then, samples were chemically reduced at a temperature of $400{ }^{\circ} \mathrm{C}$ by purging with $5 \% \mathrm{H}_{2}$ and $95 \%$ $\mathrm{N}_{2}$ gas mixture to produce a fine $\mathrm{Pt}$ distribution on zeolite. The following equations present the $\mathrm{Pt}$ oxidation and reduction reactions [8]:

Oxidation

$$
\left[\mathrm{Pt}\left(\mathrm{NH}_{3}\right)_{4}\right]^{2+}=\mathrm{NH}_{3} \text { (gas) }+\mathrm{Pt}^{2+}
$$

$\mathrm{O}_{2}($ gas $)+2 \mathrm{Pt}^{2+}=2 \mathrm{PtO}$

Reduction:

$$
\mathrm{PtO}+\mathrm{H}_{2} \text { (gas) }=\mathrm{H}_{2} \mathrm{O}+\mathrm{Pt}
$$

For sample ion exchanged with $\mathrm{NH}_{4} \mathrm{NO}_{3}$ salt (prior to the adding of the $\mathrm{Pt}\left(\mathrm{NH}_{3}\right)_{4}\left(\mathrm{NO}_{3}\right)_{2}$ salt), the sample was heated at $300{ }^{\circ} \mathrm{C}$ in argon to produce a fine distribution of the excess $\mathrm{H}^{+}$ions on zeolite framework using the reaction in equation (4) below. The Pt oxidation and reduction reactions after the introducing of $\left[\mathrm{Pt}\left(\mathrm{NH}_{3}\right)_{4}\right]^{2+}$ ions were followed by the same procedure presented in equations (1) $-(3)$.

$$
\mathrm{NH}_{4}^{+}=\mathrm{H}^{+}+\mathrm{NH}_{3} \uparrow
$$

\subsection{Electrochemical Cell and Cyclic Voltammetry}

The electrode was made of electrocatalyst with $1.5 \mathrm{wt} \%$ and $5 \mathrm{wt} \% \mathrm{Pt}$ loading on zeolite and (untreated) XC-72R carbon powder mixture mixed with 15 wt\% Nafion ${ }^{@}$ solution (i.e. 5 wt\% solution in Aliphatic Alcohols and $\mathrm{H}_{2} \mathrm{O}$ from Aldrich) as a binder. The resultant paste was then hot pressed on a sheet of $9 \mathrm{~cm}^{2}$ carbon paper (E-TEK TGHP-90) for solidification. A disc of $2.5 \mathrm{~cm}^{2}$ diameter of electrodes was then trimmed for $\mathrm{CV}$ measurement and a disc of $1.3 \mathrm{~cm}^{2}$ for in-situ EXAFS measurement.

The charge separation on electrode was investigated in a glass-jacketed electrochemical cell, consisting of working electrode, $\mathrm{Hg} / \mathrm{Hg}_{2} \mathrm{SO}_{4}$ Mercury/Mercuries Sulphate (MMS) reference electrode and a Pt gauze counter electrode. The in-situ EXAFS measurement was carried out in an electrochemical cell formed by two acrylic discs with two Kapton windows cut in the middle, accomplished by a working electrode connected with a gold wire current collector to reinforce the contact in the cell system via Pt gauze count electrode. The $\mathrm{Hg} / \mathrm{Hg}_{2} \mathrm{SO}_{4} \mathrm{MMS}$ reference electrode was then connected to the electrochemical cell using a salt bridge, re-assembled to produce a 
sufficiently large absorption edge. The electrolyte was $2.5 \mathrm{~mol} \mathrm{dm}{ }^{-3}$ sulphuric acid $\left(\mathrm{H}_{2} \mathrm{SO}_{4}\right)$ solution for the standard CV measurement and $1 \mathrm{~mol} \mathrm{dm}^{-3}$ for the in-situ EXAFS measurement at a scan rate of $1 \mathrm{mV} \mathrm{s}^{-1}$ in a potential region of $-0.65 V$ to $0.5 \mathrm{~V}$, respectively, in which no solvent and electrolyte decomposition were detected [28].

For electro-oxidation reaction of $\mathrm{HCOOH}$ and $\mathrm{CH}_{3} \mathrm{OH}$ species on Pt surface, the $\mathrm{CV}$ measurement was taken at $1 \mathrm{mV} \mathrm{s}^{-1}$ in an electrochemical cell containing $2.5 \mathrm{~mol} \mathrm{dm}{ }^{-3}$ sulphuric acid $\left(\mathrm{H}_{2} \mathrm{SO}_{4}\right)$ and $1 \mathrm{~mol}$ $\mathrm{dm}^{-3}$ methanol or formic acid solution, until a clear and stable CV curve obtained.

\subsection{The Extended X-ray Adsorption Fine Structure Measurement}

EXAFS measurements were performed using a Synchrotron Radiation Source (SRS) at STFC Daresbury Laboratory, UK. The wiggler beam line was operated at conditions of $2 \mathrm{GeV}$ and $100 \mathrm{~mA}$. High-order harmonics that might affect the amplitude of EXAFS were removed using a double-crystal Si220 monochromator. The $50 \%$ detuning of harmonic beam using gas ion chambers filled with $\mathrm{Ar}, \mathrm{Xe}$ or $\mathrm{Kr}$ and He was used to locate the Pt $\mathrm{L}_{\text {III }}$ absorption edge. A Pt foil was used as a reference sample for EXAFS data collection.

Data analysis was carried out using in-house software EXCURV 98. The inter-atomic distance, atom number and the type of backscattering neighbours were determined using a method proposed by Abruna [29].

\section{Results and Discussion}

\subsection{Zeolite Brunauer-Emmett-Teller (BET) surface area measurement}

Figure 1 depicts the zeolite BET surface area measurement to investigate zeolite structure change, owing to the calcination $\left(\mathrm{O}_{2}\right)$ and reduction $\left(\mathrm{H}_{2}\right)$ processes. The maximum $10 \%$ measurement uncertainty given by sample 15Ptancr4 (i.e. at $168 \mathrm{~m}^{2} \mathrm{~g}^{-1}$ ) (see in table 1 ) is mainly due to the significant loss of zeolite crystal structure with merely $26.97 \%$ zeolite surface area preserved. The plain zeolite sample has shown the highest surface area measured at $623 \mathrm{~m}^{2} \mathrm{~g}^{-1}$. By comparing to plain zeolite, it was found that about $86.52 \%$ of zeolite surface area was preserved by sample 15 Ptanxcr4 (i.e. at $539 \mathrm{~m}^{2} \mathrm{~g}^{-1}$ ), $90.37 \%$ and $88.76 \%$ by samples 5 Ptanxcr4 (i.e. at $563 \mathrm{~m}^{2} \mathrm{~g}^{-1}$ ) and 5 Ptancr4 (i.e. at $553 \mathrm{~m}^{2} \mathrm{~g}^{-1}$ ), respectively [30]. These data indicate that zeolite crystal structure is able to be well-preserved in the presence of excess $\mathrm{H}^{+}$ions (e.g. sample 15Ptanxcr4 or 5Ptanxcr4) during the calcination and reduction processes. The collapse of crystallized zeolite structure is found predominant for $1.5 \% \mathrm{Pt}$ loading sample $15 \mathrm{Ptancr} 4$ without $\mathrm{H}^{+}$ion presence, possibly owing to the blockage of zeolite opening pores in small channels.

The surface area measured for XC-72R carbon powder is about $32.1 \%$ (i.e. at $200 \mathrm{~m}^{2} \mathrm{~g}^{-1}$ ) compared to that of plain zeolite, slightly higher than the value given by sample 15Ptancr4. The carbon powder is only used as electrode binding paste in assisting to mix the Pt zeolite catalyst and Nafion ${ }^{\circledR}$ polymer solution. 


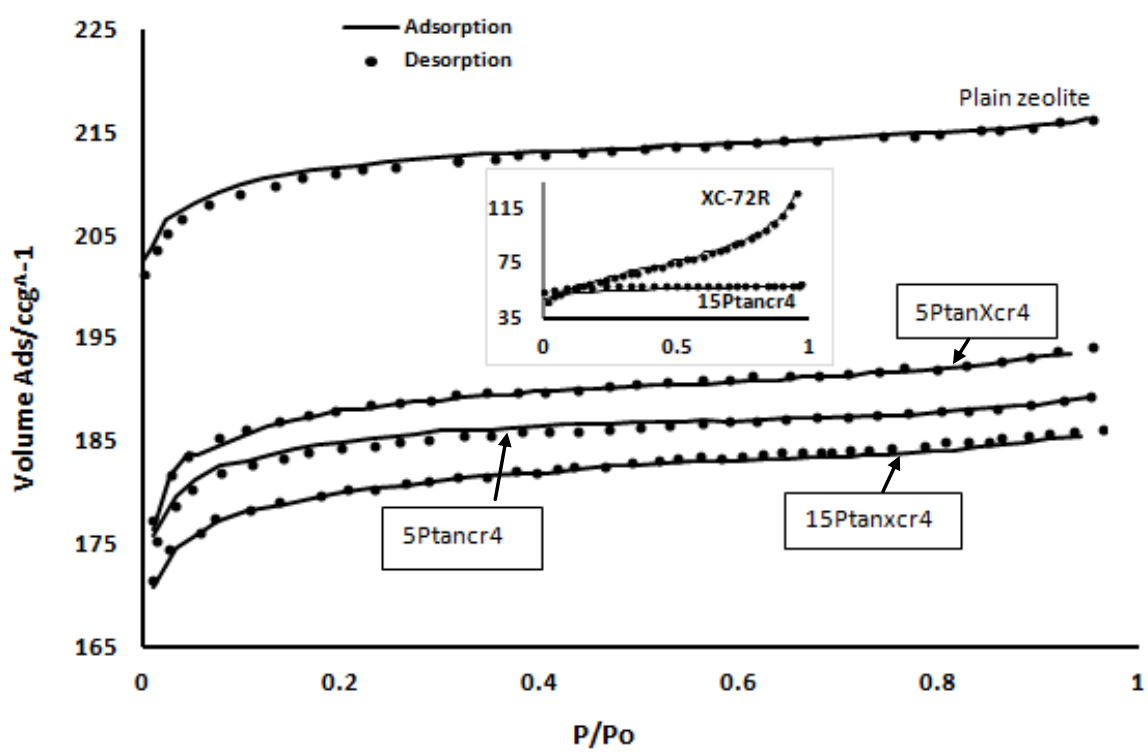

Fig. 1. Volumetric uptake of Nitrogen at a temperature of 77 Kelvin with adsorption in black solid lines and desorption in dotted symbols. All samples were made by calcination at $350{ }^{\circ} \mathrm{C}$ and reduction at $400{ }^{\circ} \mathrm{C}$, respectively.

Table 1 BET Surface area measurement.

\begin{tabular}{|l|l|l|l|l|l|l|}
\hline Sample & Plain zeolite & XC-72R & 15Ptancr4 & 15Ptanxcr4 & 5Ptancr4 & 5Ptanxcr4 \\
\hline $\begin{array}{l}\text { Surface } \\
\text { area }\left(m^{2} g^{-1}\right)\end{array}$ & $623.2 \pm 0.1 \%$ & $200 \pm 0.1 \%$ & $168 \pm 10 \%$ & $539 \pm 1.0 \%$ & $553 \pm 1.0 \%$ & $563 \pm 1.5 \%$ \\
\hline $\begin{array}{l}\text { Surface } \\
\text { area } \\
\text { preserved }\end{array}$ & $100 \%$ & $32.10 \%$ & $26.97 \%$ & $86.52 \%$ & $88.76 \%$ & $90.37 \%$ \\
\hline
\end{tabular}

\subsection{Cyclic Voltammetry measurement in $\mathrm{H}_{2} \mathrm{SO}_{4}$ electrolyte solution}

CV measurement was performed to determine the electro-activity of chemical species in the electrolyte solution on Pt surface by monitoring the current change against the potential. Figure 2 depicts a comparison of electrochemical activity between $-0.65 \mathrm{~V}$ and $0.5 \mathrm{~V}$ for samples 15Ptancr4, 15Ptanxcr4, 5Ptancr4 or 5 Ptanxcr4 Pt/ $\mathrm{Y}$ zeolite | Nafion ${ }^{@}$ bound working electrodes made by electrocatalyst with extra carbon powder mixture, respectively. The observed CV profile consists of very similar electrochemical behaviour with two distinguished hydrogen adsorption (HSP) and hydrogen reduction (HR) regions associated with the hydrogen adsorption peak (peak ' $A$ '), hydrogen evaluation peak (peak ' $B$ '), the re-oxidation peak (peak ' $C$ ') and desorption peak (peak ' $D$ '), respectively.

212 A double layer (DL) current was measured at a potential range of $-0.22 \mathrm{~V}$ to $-0.40 \mathrm{~V}$ and $-0.5 \mathrm{~V}$ to -

$2130.33 \mathrm{~V}$, during both cathodic and anodic sweeps. The current change in the hydride region provided 214 by the electrode 15Ptanxcr4 has seen significantly larger in terms of magnitude, with a well-resolved 
hydrogen oxidation peak captured at $-0.64 \mathrm{~V}$. The electrode 15 Ptancr4 predicted a hydrogen adsorption peak being further shifted towards a positive potential direction at $-0.58 \mathrm{~V}$, compared to $0.62 \mathrm{~V}$ and $-0.61 \mathrm{~V}$ determined by those of $5 \mathrm{Ptancr} 4$ and $5 \mathrm{Ptanxcr} 4$, respectively. This indicated that the energy level of hydrogen adsorption on Pt active sites for the electrode 15Ptanxcr4 was relatively high. No visible feature of hydrogen desorption peak ' $D$ ' was observed by the electrode 15 Ptancr4, possibly due to very similar energy levels of these two sites, leading to insignificant oxidation and reduction redox surface group presence. The increase of hydrogen oxidation peak current was found to follow the order of samples as 15Ptanxcr4 -> 5Ptanxcr4 $\rightarrow$ 5 Ptancr4 $->$ 15Ptancr4. There was a weak hydrogen desorption peak captured in the anodic sweep by the electrodes 5 Ptanxcr4 and 5 Ptancr4, consistent to that shown by the electrode 15 Ptanxcr4.

The presence of electron transfer at the electrode and solution interface was evidenced by the hydrogen adsorption, evolution and desorption peaks in hydride region. It was known that Pt electrocatalytic performance was closely associated with Pt particle sizes and their distributions on zeolite [14], due to the polarization of $\mathrm{Pt}$ particles by neighbouring cations, i.e. $\mathrm{H}^{+}$, resulting in $\mathrm{Pt}$ electron deficiency. The significant hydrogen adsorption and evolution current change given by the electrode 15Ptanxcr4 has indicated the presence of high Pt distribution on zeolite.

Following equations describe an oxidation/reduction process on Pt surface:

$$
\begin{aligned}
& \mathrm{Pt}+\mathrm{H}_{2} \mathrm{O}=\mathrm{OHPt}+\mathrm{H}^{+}+\mathrm{e}^{-} \\
& \mathrm{OHPt}=\mathrm{PtO}+\mathrm{H}^{+}+\mathrm{e}^{-} \\
& \mathrm{PtO}+\mathrm{H}^{+}=\mathrm{Pt}+\mathrm{OH}^{-} \\
& \mathrm{PtO}+2 \mathrm{H}^{+}=\mathrm{Pt}+\mathrm{H}_{2} \mathrm{O}
\end{aligned}
$$

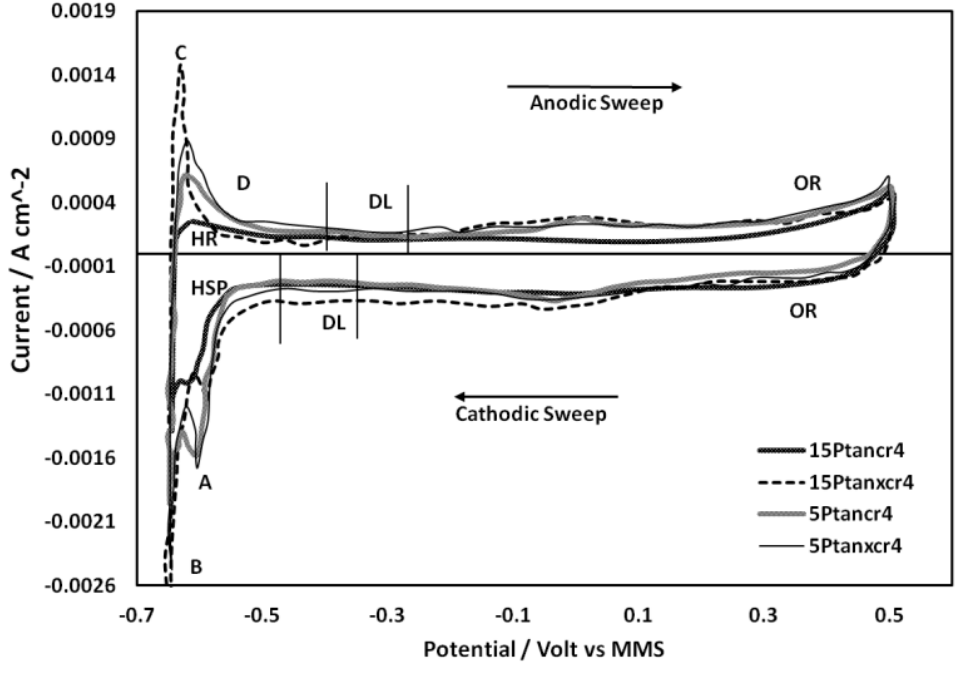

Fig. 2. The $\mathrm{CV}$ measurement in $1.0 \mathrm{~mol} \mathrm{dm} \mathrm{m}^{-3} \mathrm{H}_{2} \mathrm{SO}_{4}$ solution for a potential range of $-0.65 \mathrm{~V}$ to $0.5 \mathrm{~V}$ vs MMS reference electrode by the electrodes 15Ptanxcr4, 5Ptanxcr4, 15Ptancr4 and 5Ptancr4, respectively. 
A dramatic arising of electrochemical activity was not observed by increasing Pt loading up to $5 \mathrm{wt} \%$. The current change at the hydride region for the electrode $15 \mathrm{Ptanxcr} 4$ is about $5.1 \mathrm{~mA}$, compared to that of $3 \mathrm{~mA}$ measured for the electrodes 15 Ptancr 4 and 5 Ptancr 4 or 5 Ptanxcr4. The discrepancy may be due to following two reasons given by the electrode 15Ptanxcr4: (1) the Pt distributions on zeolite may have been increased; and (2) the Pt particle size is relatively small, resulting in an increase of Pt surface area thus promoting Pt active sites [8, 11]. The formation of the Pt-H adduct in zeolite structure can assist to diminish the sintering of Pt particle during calcinations process, due to the increase of the Pt charge density. The hydrogen adsorption and desorption was found to take place on Pt active sites via hydrogen 'spillover' pathway using carbon made Pt electrode [31], where Pt not in direct contact with Nafion ${ }^{@}$ membrane has been involved in an interfacial process through surface conductance and surface diffusion process [20]. The $\mathrm{H}^{+}$ions were able to form an $\mathrm{OH}$ group with carbon acidic surface oxides. The electrochemical conductivity in the $\mathrm{Pt} / \mathrm{Y}$ zeolite carbon powder mixed | Nafion ${ }^{@}$ electrode system might adopt a similar process of either the surface mobility of adsorbed species or the hydrogen adatoms $/ \mathrm{H}^{+}$ions 'spillover' through the electrode surface via ionic conduction of solution [3, 20]. Zeolite can act as an electron bank to donate or receive electrons, resulting in a 'flow' of protons along acidic sites [32] for $\mathrm{H}^{+}$ions being transmitted between Pt active sites on zeolite.

The water was also found to have played a significant role in electrochemical reaction to migrate hydrogen between $\mathrm{Pt}$ on zeolite framework by creating zeolite proton conducting membrane strengthening electrode surface conductivity $[3,33]$. The electrochemical reaction might involve a charge/electron transfer at the electrode and solution interface in the presence of $\mathrm{H}^{+}$and $\mathrm{H}_{3} \mathrm{O}$ free species, where ions are transferred by hitching a ride on water during their migration through zeolite channels [3].

\subsection{In-situ EXAFS study for $1.5 w t \%$ and $5 w t \%$ Pt/Y zeolite electrocatalysts}

The in-situ EXAFS data was collected at the Pt $\mathrm{L}_{\text {III }}$ edge at room temperature under a potential deposition of $-0.65 \mathrm{~V}$ vs MMS reference electrode in $1.0 \mathrm{~mol} \mathrm{dm}{ }^{-3} \mathrm{H}_{2} \mathrm{SO}_{4}$ solution. The data was then fitted in R-space by $k^{3}$ weighting and the EXAFS spectra were dominated by high Z-value neighbours with phase correction using a computer code EXCURV 98 developed at Daresbury Laboratory, UK.

\subsubsection{Pt particle analysis for $P t / Y$ zeolite electrocatalyst without excess $\mathrm{H}^{+}$incorporated in zeolite structure}

Figure 3a illustrates the data fitting of the raw EXAFS Chi spectrum $\left(k^{3} \chi(k)\right.$ vs $\left.k / \AA\right)$ for electrode 15 Ptancr4 and their fitted results being presented in table 2 . Some data scatterings were observed in Chi spectrum at a slightly high noise level [30]. EXAFS data was subsequently fitted up to 3 shells with a data fitting quality parameter called goodness fitting value $\left(R_{\text {exfd }}\right)$ of $58 \%$ approximately. The curve fitting (in dotted symbols) matches well against the raw data (in solid lines), with shells 1 and 2 Pt-Pt coordination numbers predicted at 7.45 and 2.0, respectively. The data fitting quality was improved by adding a Pt-O shell. This might be attributed by $\mathrm{Pt}$ in direct contact with the zeolite support oxygen. The Pt-Pt binding distance is determined at $2.77 \AA$, longer than a standard Pt-Pt binding distance of $2.75 \AA$. This might be introduced by the re-oxidation of $\mathrm{OH}^{-}$ions on the Pt active sites, where the energy level is coherent to that required for the re-oxidation of $\mathrm{OH}^{-}$ions. 
299

300

301

Figure $3 \mathrm{~b}$ depicts the EXAFS spectra fitted for electrode 5Ptancr4. Up to four Pt shells were predicted with Pt coordination numbers of 6.78 at shell $1,1.29$ at shell $2,3.10$ at shell 3 and 6.3 at shell 4 , respectively. The Pt-Pt binding distance is fitted at $2.76 \AA$. The increase of a Pt bond distance by 0.1 $\AA$ is possibly due to the $\mathrm{H}$ adsorption on the Pt surface and hydrogen evaluation. It might also be associated with the interference of the negative charged zeolite support oxygen atom and $\mathrm{Pt}$ particles. No Pt neighbouring oxygen atom was detected; implying Pt particle is fully reduced at $0.65 \mathrm{~V}$. The Pt particle size is estimated larger for $5 \mathrm{wt} \% \mathrm{Pt}$ loading sample than those of $1.5 \mathrm{wt} \% \mathrm{Pt}$ loading electrocatalysts predicted by Benfield theory [34] using icosahedrons or cubo-octahedron model.


(a) 15 Ptancr4
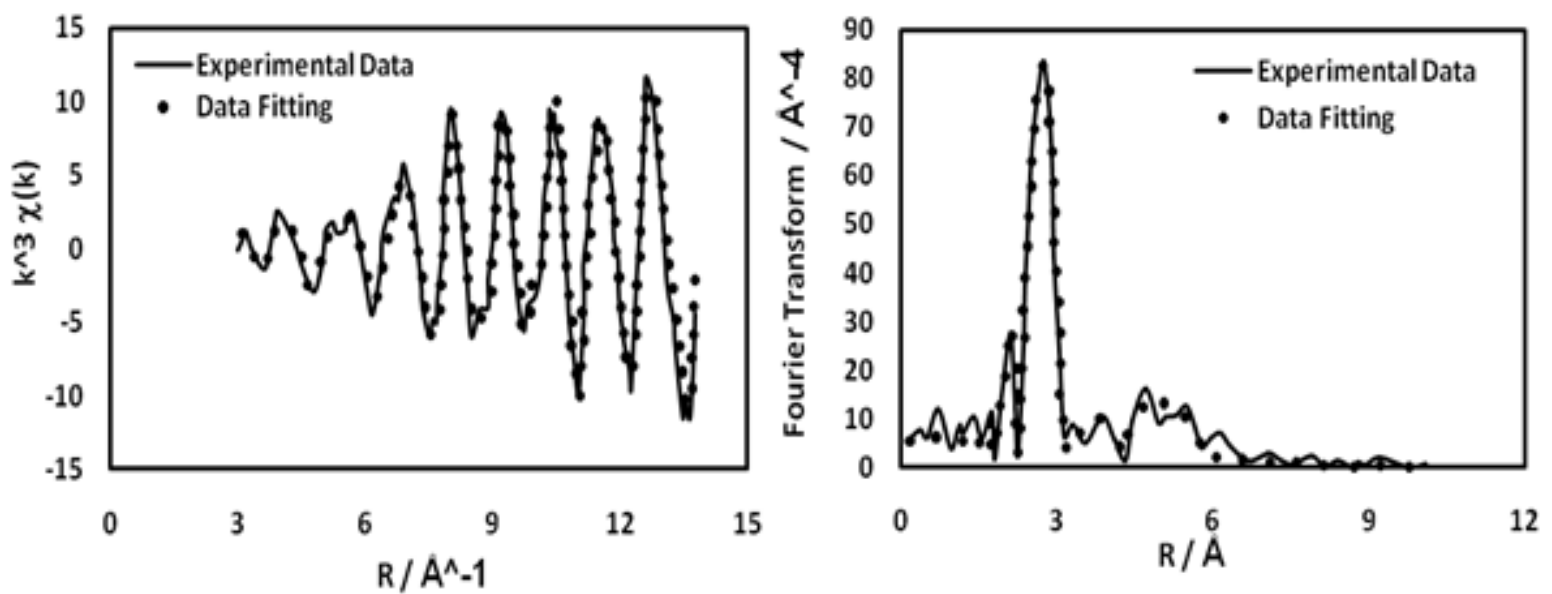

(b) 5 Ptancr4

Fig. 3. EXAFS data fitted at the Pt $L_{\text {III }}$ edge with phase correction. The experimental data and their fitting results are presented in solid lines and dotted symbols, respectively. Data were collected under a potential disposition at $-0.65 \mathrm{~V}$ vs MMS reference electrode in $1.0 \mathrm{~mol} \mathrm{dm}^{-3} \mathrm{H}_{2} \mathrm{SO}_{4}$ solution. Samples: (a) 15Ptancr4; (b) 5Ptancr4, both without excess $\mathrm{H}^{+}$ions.

3.3.2. Pt particle analysis for $P t / Y$ zeolite electrocatalyst with excess $\mathrm{H}^{+}$ions incorporated in zeolite structure 
321

Figure 4 shows EXAFS spectra fitting for electrocatalysts 15Ptanxcr4 and 5Ptanxcr4 decorated with excess $\mathrm{H}^{+}$ions on $\mathrm{Y}$ zeolite. A high noise level was shown in raw data of Chi spectrum by sample 15Ptanxcr4, resulted in a slightly poor data quality [30]. The fitting results have been improved by adding the Pt-Pt third shell. This can be confirmed by the reduction of $R_{\text {exafs }}$ value to $44.99 \%$ approximately. The Pt-Pt first shell coordination number is fitted at 6.38 , and that of shells $2 \& 3$ are predicted at 1.48 and 5.15 , respectively. The Pt-Pt binding distance is predicted at $2.77 \AA$, greater than $2.75 \AA$ of sample 5 Ptanxcr4, possibly attributed by the adsorption of hydrogen $(\mathrm{H})$ on Pt surface or hydrogen evolution. No Pt-O shell was determined around Pt centre atom.

The goodness fitting value of $R_{\text {exafs }}$ for sample 5 Ptanxcr4 was predicted at $32.24 \%$, approximately. Up to the fourth Pt-Pt shell was fitted with shell 1 Pt-Pt coordination number of 6.78 , shell 2 at 1.29 , shell 3 at 3.10 and shell 4 at 6.3 , respectively. The Pt-Pt binding distance is $2.75 \AA$, indicating that Pt particle is metallic in nature to preserve the bulk Pt property.
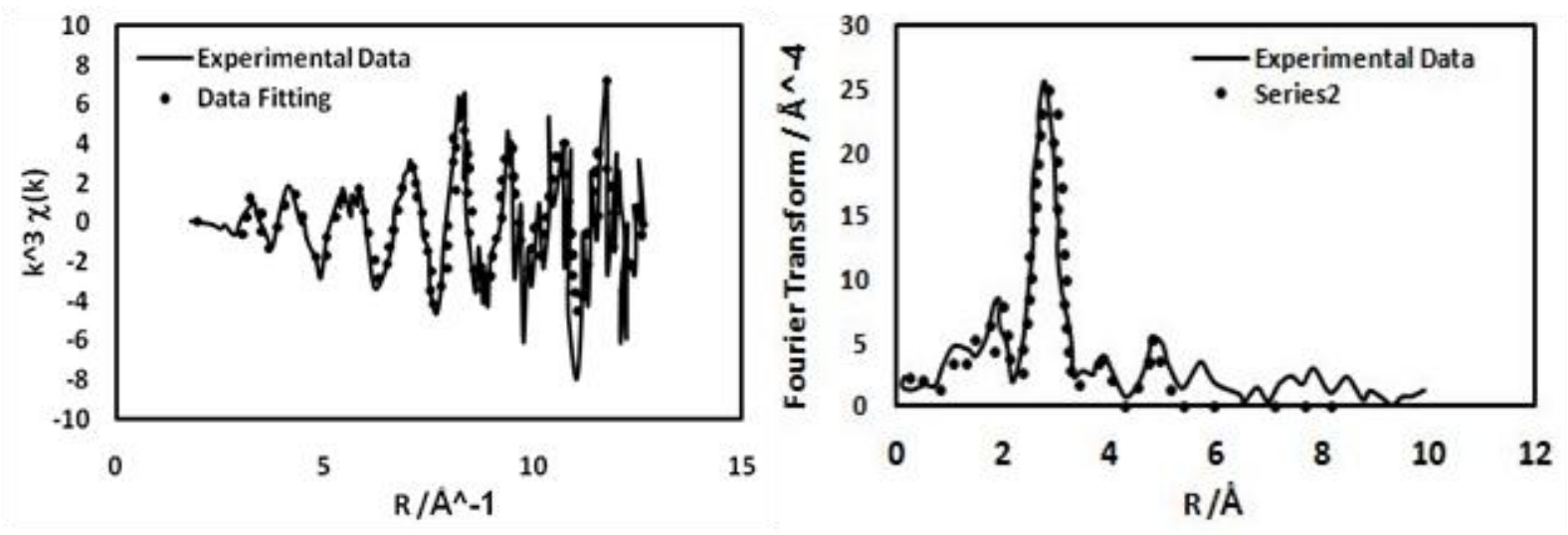

(a) 15 Ptanxcr4
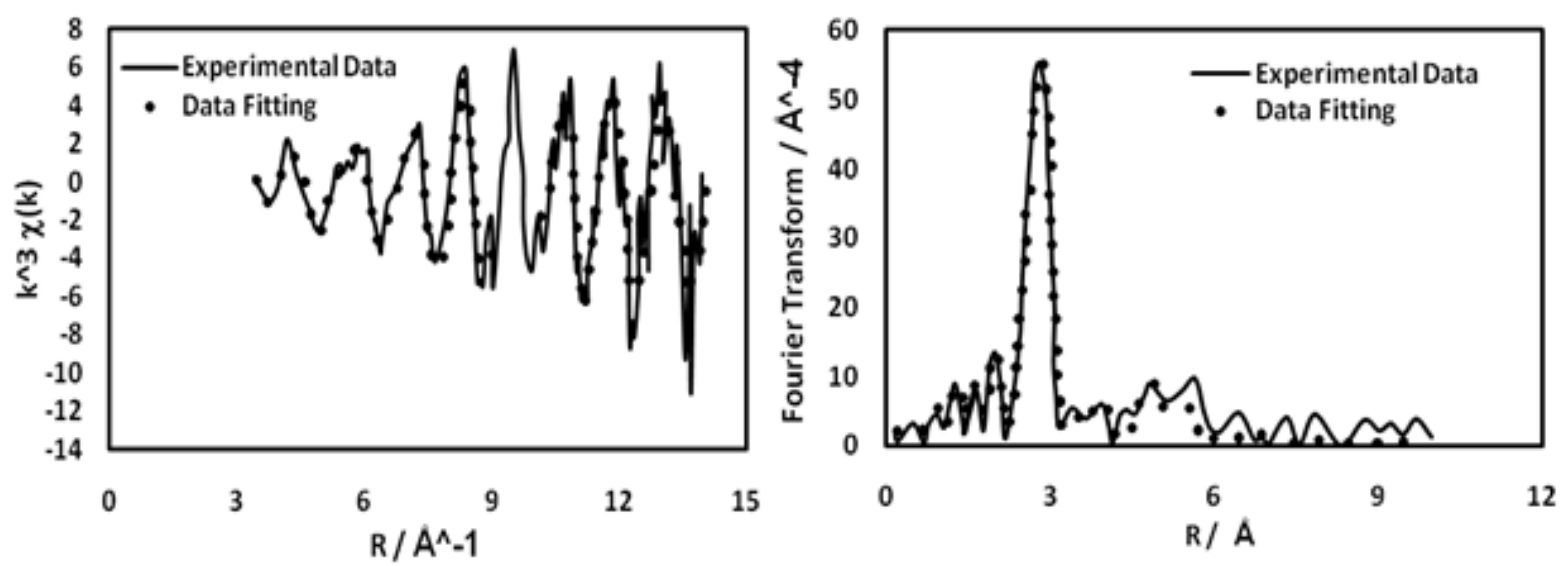

(b) $5 P \tan x c r 4$

Fig. 4. EXAFS data fitted at the Pt $L_{\text {III }}$ edge with phase correction. The experimental data and their fitting results are presented in solid lines and dotted symbols, respectively. Data were collected under a potential deposition at $-0.65 \mathrm{~V}$ vs MMS reference electrode in $1.0 \mathrm{~mol} \mathrm{dm} \mathrm{m}^{-3} \mathrm{H}_{2} \mathrm{SO}_{4}$ solution. Samples: (a) 15Ptanxcr4; (b) $5 \mathrm{Ptan} x c r 4$, both with excess $\mathrm{H}^{+}$ions. 
Table 2 EXAFS data fitting results for $1.5 \mathrm{wt} \%$ and $5 \mathrm{wt} \% \mathrm{Pt}$ loading Pt/Y zeolite electrocatalyst without excess $\mathrm{H}^{+}$ions (i.e. 15Ptancr4, 5Ptancr4) or with excess $\mathrm{H}^{+}$ions (i.e. 15Ptanxcr4, 5Ptanxcr4) in presence. The EXAFS data were collected under a potential deposition at $-0.65 \mathrm{~V}$ in $1.0 \mathrm{~mol} \mathrm{dm^{-3 }}$ $\mathrm{H}_{2} \mathrm{SO}_{4}$ solution at room temperature, respectively.

\begin{tabular}{|c|c|c|c|c|c|c|}
\hline Samples & & Shell 1-0 & Shell $2-\mathrm{Pt}$ & Shell 3-Pt & Shell 4-Pt & Shell 5-Pt \\
\hline 15Ptancr4 & $\begin{array}{l}\mathrm{N} \\
\mathrm{R}(\AA ̊)\end{array}$ & $\begin{array}{l}0.75 \\
2.19\end{array}$ & $\begin{array}{l}7.45 \\
2.77\end{array}$ & $\begin{array}{l}2.05 \\
3.85\end{array}$ & & \\
\hline 5Ptancr4 & $\begin{array}{l}\mathrm{N} \\
\mathrm{R}(\AA ̊)\end{array}$ & & $\begin{array}{l}6.78 \\
2.76\end{array}$ & $\begin{array}{l}1.29 \\
3.89\end{array}$ & $\begin{array}{r}3.10 \\
4.78\end{array}$ & $\begin{array}{r}6.30 \\
5.43\end{array}$ \\
\hline 15Ptanxcr4 & $\begin{array}{l}\mathrm{N} \\
\mathrm{R}(\AA ̊)\end{array}$ & & $\begin{array}{l}6.38 \\
2.77\end{array}$ & $\begin{array}{l}1.48 \\
3.90\end{array}$ & $\begin{array}{l}5.15 \\
4.80\end{array}$ & \\
\hline 5Ptanxcr4 & $\begin{array}{l}\mathrm{N} \\
\mathrm{R}(\AA ̊)\end{array}$ & & $\begin{array}{l}5.71 \\
2.75\end{array}$ & $\begin{array}{l}1.50 \\
3.87\end{array}$ & $\begin{array}{l}4.07 \\
4.77\end{array}$ & $\begin{array}{l}5.40 \\
5.40\end{array}$ \\
\hline
\end{tabular}

\subsubsection{The ex-situ EXAFS measurement}

Although no additional Pt-Pt third shell is predicted for the electrode 15Ptancr4 by in-situ EXAFS measurement, this does not indicate that an average size of $\mathrm{Pt}$ is small owing to the presence of $\mathrm{O}$ neighbouring atom around the centre of Pt. This has been confirmed by the deterioration of the goodness fitting value of $R_{\text {exafs }}$ at $58.87 \%$, compared to that of $44.99 \%\left(R_{\text {exafs }}\right)$ determined for the electrode 15Ptanxcr4. Subsequently, the ex-situ EXAFS analysis was carried out for a further investigation of Pt particle sizes and their distributions on zeolite.

Table 3 presents the fitting results of EXAFS data measured in $\mathrm{H}_{2}$ gas cell using a mixture of $1.5 \mathrm{wt} \%$ or $5 \mathrm{wt} \% \mathrm{Pt} / \mathrm{Y}$ zeolite and boron nitride powder placed between two pieces of plastic film. There is no ' $\mathrm{O}$ ' atom being predicted for $1.5 \mathrm{wt} \%$ Pt sample, indicating Pt might be fully reduced by $\mathrm{H}_{2}$ gas. A Pt-Pt binding distance was measured to be $2.75 \AA$. The Pt fitting results for sample $15 \mathrm{Ptancr} 4$ are in good agreement with that given by Tzou et al. [35]. An average of Pt particle size consists of $17 \mathrm{Pt}$ atoms, significantly higher than the value determined by in-situ measurement.

The number of Pt atoms determined by sample 15Ptanxcr4 in $\mathrm{H}_{2}$ gas cell consists of 13 atoms in a Pt particle, less than that in sample 15Ptancr4 under electrochemical reaction. This is possibly associated with the reduction of Pt thermal disorder in zeolite system with the increase of Pt binding energy by forming Pt metal proton adduct on zeolite acidic sites during the precursor thermal treatment process [36]. 
For $5 \mathrm{wt} \%$ Pt loading samples (i.e. 5 Ptancr4 and 5 Ptanxcr4) in $\mathrm{H}_{2}$ gas phase, the Pt particle size is predicted slightly higher than those determined in electrolyte solution. The data fitting has shown an oxidation of sample 5Ptanxcr4 with $\mathrm{O}$ atom detected around the centre of Pt atoms. The Pt-O binding distance is significantly shortened from $2.2 \AA$ to $1.93 \AA$, indicating the increase of an average Pt $d$-orbital binding energy with the increase of charge density on the zeolite support oxygen brought by charge compensation cations of $\mathrm{H}^{+}$ions [14]. The Pt-Pt binding distance is determined at $2.75 \AA$, again reflecting the metallic nature of Pt cluster.

Conclusively, a high level of Pt distributions on zeolite is acquired by samples, i.e. 15Ptanxct4 and $5 \mathrm{Ptanxcr} 4$ with excess $\mathrm{H}^{+}$ions presence. This has been demonstrated by hydrogen adsorption and desorption in hydride region.

Table 3 Data fitting results for $1.5 \mathrm{wt} \%$ and $5 \mathrm{wt} \% \mathrm{Pt} /$ zeolite samples in $\mathrm{H}_{2}$ gas at room temperature.

\begin{tabular}{|l|l|ccccc|}
\hline Samples & & Shell 1- O & Shell 1-Pt & Shell 2-Pt & Shell 3 - Pt & Shell 4 - Pt \\
\hline 15Ptancr4 & $\mathrm{N}$ & & 6.33 & 0.88 & 3.34 & 6.40 \\
& $\mathrm{R}(\AA)$ & & 2.75 & 3.91 & 4.78 & 5.42 \\
\hline 5Ptancr4 & $\mathrm{N}$ & & 7.47 & 0.47 & 4.53 & 6.57 \\
& $\mathrm{R}(\AA)$ & & 2.75 & 3.88 & 4.79 & 5.45 \\
& & & & & & \\
\hline 15Ptanxcr4 & $\mathrm{N}$ & & 6.00 & 1.59 & & \\
& $\mathrm{R}(\AA)$ & & 2.75 & 3.90 & & 5.93 \\
\hline 5Ptanxcr4 & $\mathrm{N}$ & 0.56 & 6.02 & 1.81 & 4.33 & \\
& $\mathrm{R}(\AA)$ & 1.93 & 2.75 & 3.89 & 4.78 \\
\hline
\end{tabular}

\subsection{Electrochemical oxidation of small organic species}

The oxidation behaviour of $\mathrm{Pt} / \mathrm{Y}$ zeolite catalysts was determined by examining the electrooxidation of small organic species, i.e. $\mathrm{CH}_{3} \mathrm{OH}$ and $\mathrm{HCOOH}$, as $\mathrm{Pt}$ is considered to be the most suitable catalyst for electrooxidation of these small organic molecules [22, 37]. The accompanied by-product of carbon monoxide (CO) to poison Pt surface is examined by $\mathrm{CV}$ measurement in a mixture solution of $2.5 \mathrm{~mol} \mathrm{dm}^{-3}$ sulphuric acid $\left(\mathrm{H}_{2} \mathrm{SO}_{4}\right)$ and $1 \mathrm{~mol} \mathrm{dm}^{-3}$ of $\mathrm{CH}_{3} \mathrm{OH}$ or $\mathrm{HCOOH}$ acid. The potential was cycled between $-0.65 \mathrm{~V}$ and $0.5 \mathrm{~V}$ at a scan rate of $1 \mathrm{mV} \mathrm{s}{ }^{-1}$, until a clear and stable $\mathrm{CV}$ being obtained. The tendency of $\mathrm{CV}$ measurement for $\mathrm{CH}_{3} \mathrm{OH}$ or $\mathrm{HCOOH}$ oxidation is generally in good agreement with that described in literatures [38-40].

Figure 5 displays the $\mathrm{CV}$ curves of $\mathrm{HCOOH}$ and $\mathrm{CH}_{3} \mathrm{OH}$ oxidation on $1.5 \mathrm{wt} \%$ and $5 \mathrm{wt} \%$ Pt loading zeolite electrocatalysts, presenting a typical current change profile characteristics, which are found consistent to those provided by a commercial Pt/C electrocatalyst (i.e. Johnson Matthey) with a 
particle size of $2.5 \mathrm{~nm}$ [38]. The $\mathrm{HCOOH}$ oxidation starts at a much negative potential region immediately after hydrogen desorption (see, e.g. figure 5a), compared to that determined in $\mathrm{CH}_{3} \mathrm{OH}$ (see, e.g. figure $5 b$ ), indicating Pt surface is more favourable for $\mathrm{HCOOH}$ oxidation than that of $\mathrm{CH}_{3} \mathrm{OH}$. In general, the electrode made by sample 5Ptanxcr4 has shown a better performance to oxidise $\mathrm{HCOOH}$ and $\mathrm{CH}_{3} \mathrm{OH}$ species. This was evidenced by a dramatic increase of oxidation/reduction current in both the cathodic and anodic sweeps, indicating that most of Pt active surface areas are free from $\mathrm{CO}$ occupation and thus available for electrochemical re-oxidation of $\mathrm{HCOOH}$ or $\mathrm{CH}_{3} \mathrm{OH}[38,39]$. A more consistent $\mathrm{CH}_{3} \mathrm{OH}$ oxidation/reduction current change was predicted by the electrodes of 15 Ptancr 4 or 15 Ptanxcr 4 and 5 Ptancr4, respectively, whilst a small discrepancy of current change was determined by an oxidation of $\mathrm{HCOOH}$. Their electrochemical activity follows a decreasing order of 5 Ptanxcr $4>5$ Ptancr $4>15$ Ptanxcr $4>15$ Ptancr 5 , respectively. The high electrocatalytic activity given by sample 5 Ptanxcr4 may be associated with Pt oxidation (PtO) state on zeolite due to the interference of Pt with zeolite neighbouring active site, such as Brønsted site (see, e.g. descriptions in sections 3.3.2 and 3.3.3). Present study has shown the increase of Pt loading, i.e. from $1 \mathrm{wt} \%$ to $5 \mathrm{wt} \%$, can promote the oxidation of $\mathrm{HCOOH}$ or $\mathrm{CH}_{3} \mathrm{OH}$, as seen in high current change, compared to that determined by a commercial Pt/C electrocatalyst at same scan rate of $1 \mathrm{mV} \mathrm{s}^{-1}$ [38]. Kaur et al. [23] also observed a similar trend using Ce decorated ZSM-5 zeolite as support. This may be due to the attribution given by the interference of metal nanocrystal oxide and zeolite Brønsted acidity of high surface area zeolite, resulting in high stability of catalyst and high electrocatalytic activity [23]. The oxidation mechanism of $\mathrm{HCOOH}$ and $\mathrm{CH}_{3} \mathrm{OH}$ on Pt electrodes was investigated by various research groups $[23,38-40]$ with similar conclusions. The final by-products given by electrochemical reaction were $\mathrm{CO}_{2}$ and $\mathrm{H}_{2} \mathrm{O}$, accompanied by intermediate species of $\mathrm{HCO}$ and $\mathrm{CO}$. The overall reactions for formic acid and methanol are presented below, respectively:

$$
\begin{aligned}
& \mathrm{HCOOH}+\mathrm{H}_{2} \mathrm{O} \longrightarrow 3 \mathrm{H}^{+}+\mathrm{CO}_{2}+\mathrm{OH}^{-}+4 \mathrm{e}^{-} \\
& \mathrm{CH}_{3} \mathrm{OH}+\mathrm{H}_{2} \mathrm{O} \longrightarrow 6 \mathrm{H}^{+}+\mathrm{CO}_{2}+6 \mathrm{e}^{-}
\end{aligned}
$$

CO was found to be the main poison species involved in the oxidation of methanol and formic acid, resulting in the slowdown of the electrochemical reaction [38-41]. This has been reflected by inhibition of hydrogen adsorption/desorption region. In general, the formation of $\mathrm{CO}_{2}$ by formic acid $(\mathrm{HCOOH})$ oxidation is much more efficient than that determined for methanol $(\mathrm{CH} 3 \mathrm{OH})[39,42,43]$, as evidenced by a high current yield between $-0.3 \mathrm{~V}$ and $0.5 \mathrm{~V}$ (see, e.g. figure $5 \mathrm{a}$ ). The present study indicates that both surface oxides and the available solution phase of $\mathrm{OH}^{-}$ions could be the source of oxygen for the oxidation of $\mathrm{CO}$, in agreement with those published findings [39, 44]. The overall fuel cell efficiency can be subsequently improved in formic acid, where the fuel crossover is much lower than that in methanol, owing to the repulsive interaction among the membrane sulfonic groups and anions [39]. The oxidation of small organic species appears to be a surface process, involving in $\mathrm{Pt}$ surface conducting and $\mathrm{H}^{+}$ion diffusion and spillover along $\mathrm{Pt}$ on zeolite. This is particularly appealing to eletcro-oxidation process of methanol, where a more visible $\mathrm{H}^{+}$evaluation/re-oxidation peak was captured by electrode 15Ptanxcr4. The $\mathrm{CO}$ oxidation/reduction current due to the disassociation of $\mathrm{CH}_{3} \mathrm{OH}$ is generally lower than that predicted by $\mathrm{HCOOH}$, attributed by higher energy density of methanol than that of formic acid. Nevertheless, the low theoretical open circuit potential of methanol can lead to poison Pt surface much easier than that presented in formic acid $[38,44]$. 
422

423

424

425

426

427

428

429

430

431

432

433

434

435

436

437

438

439

440

441

442

443

444

445

446

447

448

449

450

451

452

453

454

455

456

457
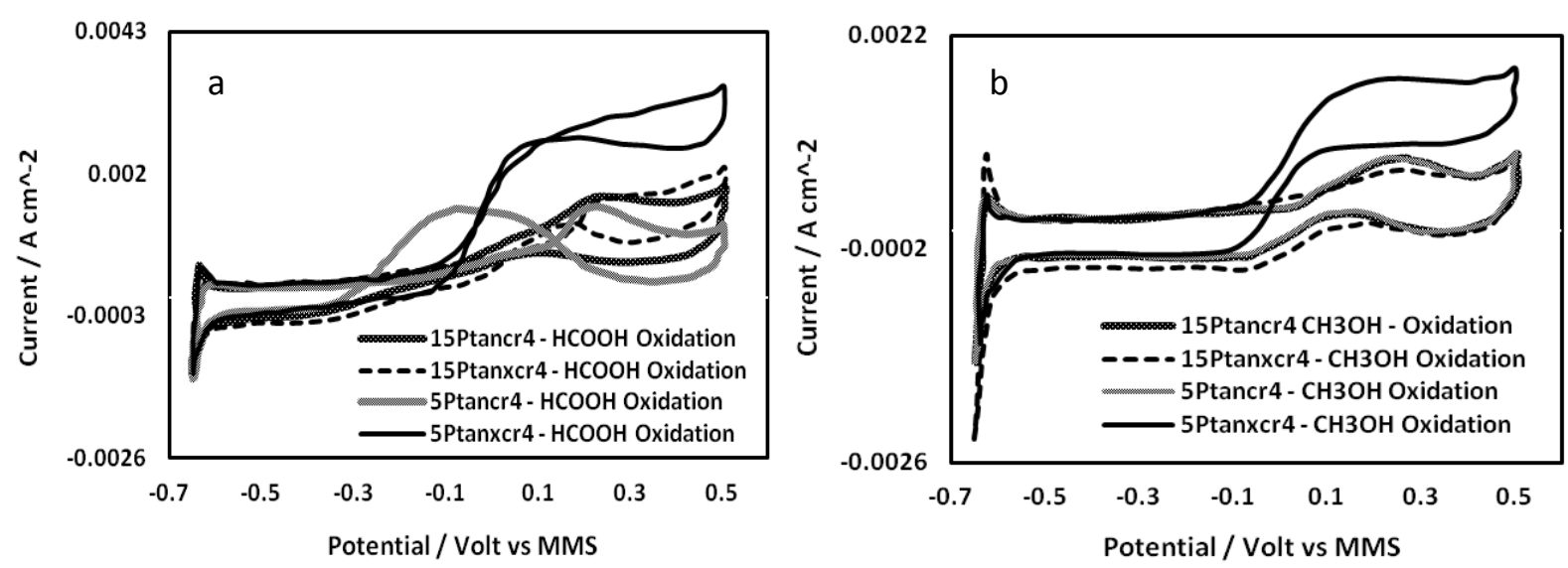

Fig. 5. The steady-state cyclic voltammetry of electrochemical oxidation of $\mathrm{HCOOH}$ and $\mathrm{CH}_{3} \mathrm{OH}$ on $\mathrm{Pt} / \mathrm{Y}$ Zeolite catalysts in a mixture solution of $2.5 \mathrm{~mol} \mathrm{dm}^{-3}$ sulphuric acid $\left(\mathrm{H}_{2} \mathrm{SO}_{4}\right)$ and $1 \mathrm{~mol} \mathrm{dm}^{-3}$ of $\mathrm{HCOOH}$ or $\mathrm{CH} 3 \mathrm{OH}$, respectively. $\mathrm{CV}$ measurement was taken until a clear stable $\mathrm{CV}$ curve obtained. (a) $\mathrm{HCOOH}$ oxidation; (b) $\mathrm{CH}_{3} \mathrm{OH}$ oxidation.

\section{Pt distribution on Y zeolite}

\subsection{Estimation of Pt particle size and Pt distribution}

The Pt particle size and its geometry were estimated by using the mean value of the first nearest neighbouring coordination number of Pt atoms as a function of Pt cluster edge length [34].

The ex-situ EXAFS measurement data was adopted to estimate the Pt particle, as seen in tables 2 and 3. This is mainly attributed by the following reasons: (1) the low goodness fitting value determined by the ex-situ data fitting, compared to those using in-situ EXAFS data; (2) Pt particles were fully reduced on zeolite in $\mathrm{H}_{2}$ gas, along with well-preserved zeolite structure (i.e. BET surface area at $539 \mathrm{~m}^{2} \mathrm{~g}^{-1}$ or for $563 \mathrm{~m}^{2} \mathrm{~g}^{-1}$ for $15 \mathrm{anxcr} 4$ or $5 \mathrm{anxcr} 4$, respectively); and (3) Pt particles might not follow icosahedral model under a potential deposition for in-situ measurement. The diameter of average Pt particle size is likely to increase in an acidic solution [46], particularly under potential deposition in hydride region. Table 4 illustrates the number of $\mathrm{Pt}$ atoms and their distributions in a Pt cluster. The Pt particle size is estimated around $1.0-1.1 \mathrm{~nm}$ in diameter with 147 atoms in a Pt cluster for sample 15Ptancr4 without excess $\mathrm{H}^{+}$ions on zeolite and $5 \mathrm{wt} \% \mathrm{Pt}$ loading samples (i.e. 5 Ptanxcr4 and 5Ptancr4). However, a significant decrease of Pt particle size down to about 0.55 $0.82 \mathrm{~nm}$ is determined for sample 15Ptanxcr4 in the presence of excess $\mathrm{H}^{+}$ions in zeolite structure, consisting of merely 13 to 55 atoms in a Pt cluster. The presence of $\mathrm{H}^{+}$ions on zeolite surface may facilitate the change of the charge density of zeolite support oxygen, resulting in a large reduction of Pt particle size. 
Table 4 The average first nearest neighbouring coordination number of $\mathrm{Pt}$ atoms and the number of Pt atoms in a Pt cluster.

\begin{tabular}{|llccc|}
\hline Acronym name & 15Ptancr4 & 15Ptanxcr4 & 5Ptancr4 & 5Ptanxcr4 $^{\text {a }}$ \\
\hline $\begin{array}{l}\overline{N_{l}} \\
\text { from refinement - Pt }\end{array}$ & 6.33 & 6.00 & 7.47 & 6.02 \\
\hline Total atom in a Pt cluster & 147 & 13,55 & 147 & 147 \\
\hline Particle size $(\mathrm{nm})$ & $1.0-1.1$ & $0.55-0.82$ & $1.0-1.1$ & $1.0-1.1$ \\
\hline
\end{tabular}

${ }^{\mathrm{a}}$ Oxygen neighbours present in the first $\mathrm{Pt}-\mathrm{O}$ coordination shell.

\subsection{Pt active surface area and distribution on zeolite}

The actual Pt loading was calculated using an edge jump from EXAFS subtraction [29]. The surface area of Pt particle was determined via hydrogen adsorption and desorption peaks captured by cyclic voltammetry measurement in $\mathrm{H}_{2} \mathrm{SO}_{4}$ solution. Table 5 illustrates a comparison of Pt distributions on zeolite for $1.5 \mathrm{wt} \%$ and $5 \mathrm{wt} \%$ Pt loading samples.

A significant high Pt surface area was determined for sample 15Ptanxcr4. The actual Pt loadings on zeolite for samples 15 Ptanxcr4 and 15 Ptancr4 are $0.77 \mathrm{wt} \%$ and $1.52 \mathrm{wt} \%$ respectively, in consistent to Pt active surface areas of $103.57 \mathrm{~m}^{2} \mathrm{~g}^{-1}$ and $51.59 \mathrm{~m}^{2} \mathrm{~g}^{-1}$. The Pt surface area is found generally low for the samples of 5Ptanxcr4 and 5Ptancr4, estimated at $32.61 \mathrm{~m}^{2} \mathrm{~g}^{-1}$ and $21.47 \mathrm{~m}^{2} \mathrm{~g}^{-1}$, with correspondent to Pt loadings of $4.71 \mathrm{wt} \%$ and $7.76 \mathrm{wt} \%$, respectively. The prepared Pt loading on zeolite for samples 15Ptancr4 and 5Ptanxcr4 is found consistent with the measured values for 1.5 $w t \%$ and $5 \mathrm{wt} \% \mathrm{Pt}$ loading on $\mathrm{Y}$ zeolite, whilst either a significant low or a significant high value is determined for samples 15Ptanxcr4 and 5Ptancr4, respectively.

The net Pt atoms per $\mathrm{cm}^{2}\left(N_{T}\right)$ predicted for samples 5Ptancr4, 5Ptanxcr4, 15Ptancr4 and 15Ptanxcr4 were followed an order of $26.42 \times 10^{17}>16.16 \times 10^{17}>5.21 \times 10^{17}>2.64 \times 10^{17}$ per $\mathrm{cm}^{2}$, respectively. This tendency of net Pt atom distribution per $\mathrm{cm}^{2}$ is well reflected by $\mathrm{Pt}$ loading on $\mathrm{Y}$ zeolite. The associated Pt surface atoms per $\mathrm{cm}^{2}$ on zeolite $\left(N_{S}\right)$ were determined to be $13.11 \times 10^{16}$ (for sample 5 Ptancr4) $>15.11 \times 10^{16}$ (for sample 5 Ptanxcr4) $>7.64 \times 10^{16}$ (for sample 15 Ptancr 4 ) $>7.77 \times 10^{16}$ (for sample 15Ptanxcr4), respectively. This has provided a high level of Pt surface atom dispersions (defined as $\mathrm{N}_{\mathrm{S}} / \mathrm{N}_{\mathrm{T}} \times 100 \%$ ) of $29.44 \%$ for sample $15 \mathrm{Ptan} \times \mathrm{cr} 4$, compared with the values of $14.66 \%$, $9.35 \%$ and $4.93 \%$ for samples 15 Ptancr4, 5Ptanxcr4 and 5Ptancr4, respectively. In general, the excess $\mathrm{H}^{+}$ions incorporated with $\mathrm{Pt} / \mathrm{Y}$ zeolite electrocatalyst will result in a better Pt surface atom dispersion, compared to samples with Pt loading at same level without excessive $\mathrm{H}^{+}$ion presence. The increase of Pt loading on zeolite from $1.5 \mathrm{wt} \%$ to $5 \mathrm{wt} \%$ loading does not provide a higher Pt surface dispersion.

The present study has shown that $\mathrm{H}^{+}$ions enable to achieve high Pt distribution on zeolite, owing to the change of $\mathrm{Pt} d$ bond energy state. The high Pt surface area can contribute to improve the Pt electrocatalytic activity using Nafion ${ }^{@}$ bound Pt electrode, i.e. 15 Ptanxcr4 or 5 Ptanxcr4. This has been clearly reflected by the electrochemical reactions on Pt surface as (1) hydrogen 
505

506

507

508

509

510

511

512

513

514

515

516

517

518

519

520

521

522

523

524

oxidation/reduction in hydride region in $2.5 \mathrm{~mol} \mathrm{dm}^{-3} \mathrm{H}_{2} \mathrm{SO}_{4}$ solutions, and (2) the oxidation of small organic species, i.e. $\mathrm{HCOOH}$ and $\mathrm{CH}_{3} \mathrm{OH}$ species, in a $2.5 \mathrm{~mol} \mathrm{dm}^{-3} \mathrm{H}_{2} \mathrm{SO}_{4}$ electrolyte solution containing $1 \mathrm{~mol} \mathrm{dm}-3 \mathrm{HCOOH}$ or $\mathrm{CH}_{3} \mathrm{OH}$ species. The increase of Pt loading on zeolite is able to facilitate the oxidation of $\mathrm{HCOOH}$ or $\mathrm{CH}_{3} \mathrm{OH}$ species, which supports the evidence found by Kaur et al. [23].

For electrocatalysts, i.e. $15 \mathrm{Ptan} x \mathrm{cr} 4$ and $5 \mathrm{Ptan} x \mathrm{cr} 4, \mathrm{H}^{+}$ions act in a very similar way as other ions such as $\mathrm{K}^{+}, \mathrm{Ca}^{2+}$ and $\mathrm{Fe}^{2+}$ to promote a better Pt particle distribution by anchoring Pt on the zeolite surface and supercage wall to restrain Pt migration. Present $\mathrm{CV}$ measurement implies that the Pt particle sizes and their distributions on zeolite are indeed one of major contributors to determine the Pt oxidation and reduction performance.

Table 5 The comparison of Pt distributions on zeolite for $1.5 \mathrm{wt} \%$ and $5 \mathrm{wt} \%$ Pt loading samples.

\begin{tabular}{|lcccc|}
\hline Electrocatalyst & 15Ptancr4 & 15Ptanxcr4 & 5Ptancr4 & 5Ptanxcr4 ${ }^{\mathrm{a}}$ \\
\hline Pt active surface area $\mathrm{m}^{2} \mathrm{~g}^{-1}$ & 51.29 & 103.57 & 21.47 & 32.61 \\
\hline Calculated mass quantity in wt \% & 1.52 & 0.77 & 7.76 & 4.71 \\
\hline $\mathrm{N}_{\mathrm{T}}$ Pt net atoms per $\mathrm{cm}^{2}\left(\times 10^{17}\right)$ & 5.21 & 2.64 & 26.62 & 16.16 \\
\hline $\mathrm{N}_{\mathrm{S}}$ Pt surface atoms per $\mathrm{cm}^{2}\left(\times 10^{16}\right)$ & 7.64 & 7.77 & 13.11 & 15.11 \\
& & & & \\
\hline Dispersion $\mathrm{N}_{\mathrm{S}} / \mathrm{N}_{\mathrm{T}}(\%)$ & 14.66 & 29.44 & 4.93 & 9.35 \\
\hline
\end{tabular}

Note: $\mathrm{N}_{\mathrm{T}}$ is Pt total atoms per $\mathrm{cm}^{2}$; and $\mathrm{N}_{\mathrm{S}}$ is obtained from Benfield theory.

\section{Conclusion}

This paper has presented the characteristics of zeolite supported Pt nano-particle and their electrocatalytic performances by EXAFS analysis and CV measurements. The resultant data analysis indicates that $\mathrm{H}^{+}$ions were able to restrain the mobility of Pt on zeolite during precursor thermal treatments by anchoring Pt on zeolite cage wall, leading to a high dispersion of Pt on zeolite and a better electrocatalytic performance, i.e. $15 \mathrm{Ptanxcr} 4$ and $5 \mathrm{Ptanxcr} 4$, compared to samples without the excess $\mathrm{H}^{+}$on zeolite, i.e. 15Ptancr4 and 5Ptancr4.

The Pt-Pt binding distance was measured between $2.75 \AA$ and $2.77 \AA$, indicating the metallic nature of Pt. The $0.1 \AA$ or $0.2 \AA$ increase of Pt-Pt binding distance over a standard value of $2.75 \AA$ could be attributed by either electrochemical adsorption of $\mathrm{H}$ atom on $\mathrm{Pt}$ active surface forming a $\mathrm{Pt}-\mathrm{H}$ bond or the interference of zeolite support oxygen as a result of increasing oxygen charge density. This can facilitate the oxidation of $\mathrm{CH}_{3} \mathrm{OH}$ and $\mathrm{HCOOH}$ species, as evidenced by $\mathrm{CV}$ measurement using sample such as 5 Ptanxcr4.

The hydrogen spillover pathway was explored by depicting the charger/electron transfer at Pt electrode and solution interface by either the direct charger transfer or the mobility of $\mathrm{H}_{\mathrm{ads}} / \mathrm{H}^{+}$ species on zeolite, which is a DC electrical insulator. The $\mathrm{H}^{+}$ions were found able to transmit along the zeolite surface to increase the surface conductivity of catalyst. The $\mathrm{H}^{+}$and $\mathrm{H}_{3} \mathrm{O}^{+}$ions may also 
525 lead to ionic conduction via free species by hitching a ride on water to increase the electrode surface

526 conductivity. In general, $\mathrm{HCOOH}$ has shown a better oxidation performance than that of $\mathrm{CH}_{3} \mathrm{OH}$.

\section{References}

528 [1] Min MK, Cho J, Cho K, Kim H. Particle size and alloying effects of Pt based alloy catalysts for fuel 529 cell applications. Electrochimica Acta 2000; 45: 4211-4217.

530 [2] Han W, Kwan SM, Yeung LK. Zeolite application in fuel cell: water management and proton 531 conductivity. Chemical Engineering Journal 2012; 187: 367-371.

532 [3] Breck DW. Zeolite molecular sieves: structure, chemistry and use. New York: Wiley - Interscience; 5331974.

534 [4] Rolison DR. Zeolite-modified electrodes and electrode-modified zeolites. Chemical Reviews 1990; 535 90: 867-878.

536 [5] Sachtler WMH, Zhang ZC. Zeolite-supported transition metal catalysts. Advances in Catalysis 537 1993; 39: 129-220.

538 [6] Exner D, Jaeger N, Kleine A, Schulz-Ekloff G. Reduction-agglomeration model for metal dispersion 539 in platinum-exchanged NaX zeolite. J. Chem. Soc. Faraday Trans.1: Physical Chemistry in Condensed 540 Phase 1988; 84: 4097-4104.

541 [7] Reagan WJ, Chester AW, Kerr GT. Studies of the thermal decomposition and catalytic properties 542 of some platinum and palladium ammine zeolites. J. of Catalysis 1981; 69(1): 89-100.

543 [8] Gallezot P, Alarcon-Diaz A, Dalmon JA, Renouprez AJ, Imeuk B. Location and dispersion of 544 platinum in Pt/Y zeolites. J. of Catalysis 1975; 39: 334 - 349.

545 [9] Tzou MS, Teo BK, Sachtler WMH. Formation of Pt particles in Y-type zeolites: the influence of 546 coexchanged metal cations. J. of Catalysis 1998; 113: 220-235.

547 [10] Tao L, Dou S, Ma ZL, Shen AL, Wang SY. Simultaneous Pt deposition and nitrogen doping of 548 graphene as efficient and durable electrocatalysts for methanol oxidation. International of Journal 549 Hydrogen Energy 2015; 40: 14371-14377.

550 [11] Bergeret G, Gallezot P, Imelik B. X-ray study of the activation, reduction, and re-oxidation of 551 palladium in Y-type zeolites. J. Phys. Chem. 1981; 85(4): 411-416.

552 [12] Koningsberger DC, de Graaf J, Mojet BL, Ramaker DE, Miller JT. The metal-support interaction in $553 \mathrm{Pt} / \mathrm{Y}$ zeolite: evidence for a shift in energy of metal $\mathrm{d}$-valence orbitals by $\mathrm{Pt}-\mathrm{H}$ shape resonance and 554 atomic XAFS spectroscopy. Applied Catalysis A: General 2000; 191: 205 -220.

555 [13] Mojet BL, Miller JT, Ramaker DE, Koningsberger DC. A new model describing the metal-support 556 interaction in noble metal catalysts. J. of Catalysis 1999; 186: 373-386.

557 [14] Zhang ZC, Wong TT, Sachtler WMH. The effect of $\mathrm{Ca}^{2+}$ and $\mathrm{Mg}^{2+}$ ions on the formation of 558 electron-deficient palladium-proton adducts in zeolite Y. J. of Catalysis 1991; 128: 13-22. 
559 [15] Larsen G, Haller GL. Metal-support effects in Pt/L-zeolite catalysts. Catalysis Lett. 1989; 3: 103560110.

561 [16] Pandya KI, Heald SM, Hriljac JA, Petrakis L, Fraissard J. Characterization by EXAFS, NMR, and

562

563

564

565

566

567

568

569

570

571

572

573

574

575

576

577

578

579

580

581

582

583

584

585

586

587

588

589

590

591

592 other techniques of $\mathrm{Pt} / \mathrm{NaY}$ zeolite at industrially relevant low concentration of platinum. Journal of Physical Chemistry 1996; 100(12): 5070-5077.

[17] Boyanov BI, Morriso TI. Support and temperature effects in platinum clusters 1: spatial structure. Journal of Physical Chemistry 1996; 100: 16310-16317.

[18] Yakoyama T, Kosugi N, Asakura K, Iwasawa Y, Kuroda H. Temperature dependence of the Pt L3edge EXAFS of platinum clusters supported on NaY-zeolite. Journal De Physique 1986; C8: 273-276. [19] Vaarkamp M, Modica FS, Miller JT, Koningsberger DC. Influence of hydrogen pre-treatment on the structure of the metal-support interface in Pt/zeolite catalysts. J. of Catalysis 1993; 144(2): 611626.

[20] Liu W-J, Wu B-L, Cha C-S. Surface diffusion and the spillover of H-adatoms and oxygencontaining surface species on the surface of carbon black and $\mathrm{Pt} / \mathrm{C}$ porous electrodes. J. Electroanalytical Chem. 1999; 476(2): 101-108.

[21] Zhang A, Nakamura I, Fujimoto K. A new probe reaction for studying the hydrogen spillover phenomenon. Journal of Catalysis 1997; 168(2): 328-333.

[22] Hernandez-Fernandez P, Lund PB, Kallesøe C, Clausen HF, Christensen LH. Supported Pt-based nanoparticulate catalysts for the electro-oxidation of methanol: an experimental protocol for quantifying its activity. International Journal of Hydrogen Energy 2015; 40: 284-291.

[23] Kaur B, Srivastava R, Satpati B. Highly efficient $\mathrm{CeO}_{2}$ decorated nano-ZSM-5 Catalyst for electrochemical oxidation of methanol. American Chemical Society (ACS) Catal. 2016; 6: 2654-2663. [24] Hsieh CT, Chen WY, Tzou DY, Roy AK, Hsiao HT. Atomic layer deposition of Pt nanocatalysts on graphene oxide nanosheets for electro-oxidation of formic acid. International Journal of Hydrogen Energy 2012; 37: 17873-17843.

[25] El-Nagar GA, Mohammed AM. Enhanced electrocatalytic activity and stability of platinum, gold, and nockel oxide nanoparticles based ternary catalyst for formic acid electro-oxidation. International Journal of Hydrogen Energy 2014; 39: 11955-11962.

[26] Bessel CA, Rolison DR. Micro-heterogeneous dispersion electrolysis with nano-scale electrode modified zeolite. Journal of Electro-analytical Chemistry 1997; 439: 97-105.

[27] Persaud L, Bard AJ, Campion A, Fox MA, Mallouk TE, Webber SE, White JM. A new method for depositing platinum exclusively on the internal surface of zeolite L. Inorg. Chem. 1987; 26: 3825 3827.

[28] Brett CMA, Brett AMO. Electroanalysis. Oxford University Press, 1998. 
593 [29] Abruna HD. X-ray absorption spectroscopy in the study of electrochemical system. In: HD

594 Abruna (Eds.), Electrochemical interface: modern techniques for in-Situ interface characterization.

595 New York: VCH Publishers; 1991, Chapter 1: pp.1-54

596 [30] Yao J, Yao YF. Proton modified Pt zeolite fuel cell electrocatalysts. In: Sayigh A (Eds.),

597 Renewable energy in the service of mankind, Vol 1, selected topic from world renewable energy

598 congress WPEC 2014. Springer International Publishing, Switzerland, 2015, pp. 173 -182.

599 [31] Srinivas S, Rao P. Direct observation of hydrogen spillover on carbon-supported platinum and its 600 influence on the hydrogenation of benzene. J. of Catalysis 1994; 148(2): 470-477.

601 [32] Ueda P, Kusakari T, Tomishige K, Fujimoto K. Nature of spiltover hydrogen on acid sites in 602 zeolite: observation of the behaviour of adsorbed pyridine on zeolite catalysts by means of FTIR. J. of 603 Catalysis 2000; 194(1): 14-22.

604 [33] Herrmann JM, Pichat P. Evidence by electrical conductivity measurements for hydrogen 605 spillover on $\mathrm{Pt}, \mathrm{Rh}$ and $\mathrm{Ni} / \mathrm{TiO}_{2}$ catalysts: consequences for bufunctional photocatalysis. In: Pajonk 606 GM, Teichner SJ, Germain JE, editors. Spillover of Adsorbed Species, Studies in Surface Science and 607 Catalysis. Elsevier, Amsterdam, 1983, pp. 77-88.

608 [34] Benfield RE. Mean coordination numbers and the non-metal-metal transition in cluster. J. of the 609 Chem. Soc. Faraday Trans. 1992; 88(8): 1107-1110.

610 [35] Tzou MS, Kusunoki M, Asakura K, Kuroda H, Moretti G, Sachtler WMH. Bimetallic copper611 platinum particle supported in Y zeolite: structural characterization by EXAFS. J. Phys. Chem. 1991; 612 95(13): 5210-5215.

613 [36] Rolison DR, Hayes EA, Rudzinski WE. Electrode-modified zeolites: electrode microstructures 614 contained in and on a heterogeneous catalyst. J. of Phys. Chem. 1989; 93(14): 5524-5531.

615 [37] Frelink T, Visscher W, Cox AP, van Veen JAR, Bunsenges B. The role of surface oxides in the 616 electrooxidation of methanol, formic acid and CO on Pt, Ru and codeposited Pt-Ru. Phy. Chem. 1996; 617 100: 599-606.

618 [38] Wang ZB, Chu YY, Shao AF, Zuo PJ,, Yin GP, Electrochemical impedance studies of 619 electrooxidation of methanol and formic acid on $\mathrm{Pt} / \mathrm{C}$ catalysts in acid medium, Journal of Power 620 Sources 2009; 190: 336-340.

621 [39] Lovic JD, Tripkovic AV, Gojkovic SL J, Popovic K, Tripkovic DV, Olszewski P, Kowal A. Kinetic study 622 of formic acid oxidation on carbon supported platinum electrocatalyst. J. Electroanal. Chem. 2005; $623 \quad 581: 294-302$.

624 [40] Zhao L, Wang ZB, Li JL, Zhang JJ, Sui XL, Zhang LM. Hybrid of carbon-supported Pt nanoparticles 625 and three dimensional graphene aerogel as high stable electrocatalysts for methanol 626 electrooxidation. Electrochimica Acta 2016, 189: 175-183. 
627 [41] Cai GX, Guo JW, Wang J, Li S. Negative resistance for methanol electro-oxidation on

628 platinum/carbon (Pt/C) catalyst investigated by an electrochemical impedance spectroscopy. J of

629 Power Sources 2015; 276: 279-290.

630 [42] Markovic NM, Gasteiger HA, Ross PN, Jiang XD, Villegas I, Weaver M. Electro-oxidation

631 mechanisms of methanol and formic acid on Pt-Ru alloy surfaces. Electrochimica Acta 1995; 40(1):

$63291-98$.

633 [43]. Herrero E, Franaszczuk K, Wieckowski A. Electrochemistry of methanol at low index crystal

634 planes of platinum: an integrated voltammetric and chronoamperometric study. J. Phys. Chem.

635 1994; 98: 5074-5083.

636 [44] Njagi EC, Genuino HC, King'ondu CK, Chen CH, Horvath D, Suib SL. Preferential oxidation of CO

637 in H2-rich feeds over mesoporous copper manganese oxides synthesized by a redox method.

638 International Journal of Hydrogen Energy 2011; 36: 6768-6779.

639 [45] Kang SJ, Lee JY, Lee JK, Chung SY, Tak YS. Influence of bi modification of Pt anode catalyst in

640 direct formic acid fuel cells. J. Phys. Chem. B 2006; 110: 7270-7274.

641 [46] Ranasinghe AD. Part I: In situ pulse electrochemical deposition of Pt nanoparticles for efficient

642 catalyst utilization in fuel cell. PhD Thesis, University of California Santa Barbara, 2007. Publication

643 Number: AAI3274422; ISBN: 9780549152644; Source: Dissertation Abstracts International, Volume:

644 68-07, Section: B, page: 4441; 199 p. 